\title{
From the Classroom to the Courtroom: Intelligent Design and the Constitution
}

\author{
Jay D. Wexler
}

Published online: 20 April 2010

(C) Springer Science+Business Media, LLC 2010

\begin{abstract}
Although the Supreme Court of the United States has never developed a single clear test for determining what kinds of state action violate the Establishment Clause of the First Amendment, schools that attempt to teach or introduce intelligent design as a purportedly scientific alternative to evolution likely fall afoul of the First Amendment's commands. Under the Court's most relevant precedent, Edwards v. Aguillard, teaching intelligent design violates the Establishment Clause because, among other things, there is an enormous disconnect between the purpose of teaching intelligent design and its effect. Moreover, public school teachers do not possess any First Amendment right of academic freedom to disregard the clear instructions of a school principal or district not to teach or introduce intelligent design in their classrooms.
\end{abstract}

Keywords First Amendment - Establishment Clause · Constitution · Intelligent design · Evolution .

Academic freedom

Teaching intelligent design in our nation's public school science classrooms is no doubt bad educational policy, but is it also unconstitutional? The only court to consider the issue so far answered with a resounding yes (Kitzmiller v. Dover), but since its decision lacks precedential authority outside a very small area in Pennsylvania, the question is still a live one. It is hard to say with any certainty what some other court might do if faced with another challenge to an intelligent design policy. The Supreme Court's religion clause jurisprudence is notoriously vague and indeterminate, and a lot will necessarily turn on the specific circumstances of whatever case or

J. D. Wexler $(\bowtie)$

Boston University,

Boston, MA, USA

e-mail: jaywex@bu.edu cases find their way to the courts. Despite these uncertainties, however, it is quite clear that teaching intelligent design in public science classrooms would raise serious constitutional problems in most, if not all cases, and that schools that adopt intelligent design policies run a substantial risk of losing in the courts. Here I will canvass the legal issues relevant to the adoption of an intelligent design policy in the public schools, and I will suggest that such policies, in most cases, should be found unconstitutional. I consider primarily the constitutional ramifications of a school board that adopts a formal intelligent design policy, but it is also worth noting that many of the same arguments can be applied to an individual teacher who determines on his or her own to teach intelligent design.

\section{Church-State Relations and the First Amendment}

The first sentence of the First Amendment to the United States Constitution says that "Congress shall make no law respecting an establishment of religion or prohibiting the free exercise thereof." The first part of the sentence is usually called the "Establishment Clause"; the second part is known as the "Free Exercise Clause." Although the sentence speaks only in terms of what Congress may or may not do, the Supreme Court has long held that the First Amendment in fact applies to all levels of government, including state and local bodies. Like many parts of the Constitution, the religion clauses of the First Amendment can be interpreted in many ways, and so the courts have had to struggle over the past century to clarify what kinds of actions government can and cannot take with respect to religion. It would be impossible in the space provided here to provide any kind of a comprehensive summary of the history of church-state law, so I will limit myself to a very 
brief sketch of the current law regarding the establishment of religion, with specific emphasis on the Supreme Court decisions that have set out the legal tests most relevant for the constitutional evaluation of any policy involving intelligent design.

The most general statement of Establishment Clause law is the so-called Lemon test. According to this test, first articulated by the Supreme Court in a case called Lemon v. Kurtzman, the government may not take any action that has the primary purpose of advancing religion, has the primary effect of advancing religion, or fosters an excessive entanglement between religion and the state. This general test, however, creates more questions than it answers. For example: How do we determine the government's purpose? What constitutes an advancement of religion? How much entanglement is excessive? And what counts as entanglement anyway? As a result, the Court rarely looks only to this test to decide cases. Instead, the Court applies more specific variations or elaborations of the Lemon test depending on what kind of challenge it is considering.

One such elaboration that is particularly relevant for considering the constitutionality of intelligent design policies is the endorsement test. Created by Justice Sandra Day O'Connor in a concurring opinion in 1984, and adopted by five members of the Court five years later in a case involving various holiday displays near a Pittsburgh courthouse, the test asks whether a "reasonable observer" would feel that the government has sent a "message to non-adherents that they are outsiders, not full members of the political community, and an accompanying message to adherents that they are insiders, favored members of the political community" (County of Allegheny v. ACLU). In determining whether the government has violated the test, the Court considers the entire context of the government's action, particularly the action's historical context, and measures the perception of "the reasonable observer," who "must be deemed aware of the history and context of the community and forum in which the religious display appears" (Capitol Square Review \& Advisory Board v. Pinette).

The Court has twice struck down attempts by states to interfere with evolution education. In 1968, in Epperson v. Arkansas, the Court invalidated an Arkansas law that prohibited teachers from teaching evolution, finding that the law was motivated by a completely religious purpose. About twenty years later, the Court held that Louisiana's equal time law, requiring schools to teach so-called creation science whenever presenting evolution, also violated the Establishment Clause. This decision, Edwards v. Aguillard, is the most relevant statement by the Court to date for considering whether a public school can constitutionally introduce the concept of intelligent design into science classes.
As a formal matter, the Court in Edwards decided against the statute for the same reason it invalidated the statute at issue in Epperson: It found that the statute lacked any secular purpose. But because the state had in fact claimed a secular purpose-promoting the academic freedom of public school teachers-the Court engaged in extended analysis on the way to concluding that this claimed purpose was in fact a sham. In the course of this discussion, the Court relied on several key facts and findings: (1) the poor means-end relationship of the statute, that is, the poor fit between the goal of promoting academic freedom and what the statute actually did; (2) the historic link between religion and critiques of evolution; (3) the singling out of evolution from among all possible topics in the curriculum for reform; (4) the favoring of creation science under certain provisions of the statute; and (5) statements from the legislative history indicating the legislature acted with the intent to promote religion.

Because the Court found that the statute was unconstitutional on Lemon's first prong, it did not also consider whether the statute had the unconstitutional effect of endorsing or promoting religion. But given the Court's skeptical attitude and the fact that the five factors examined by the Court probably equally supported a finding of endorsement or promotion, the Court most likely would have struck down the statute on these grounds as well, had it considered them. Since it found that the legislature had acted with a religious purpose to promote and endorse religion, the Court could only have found a lack of actual endorsement or promotion if it had found that the legislature had not in fact accomplished its goals by issuing the law, a conclusion that seems quite unlikely given the Court's attitude toward the statute.

Finally, it is worth noting that the Supreme Court has been particularly vigilant in policing the Establishment Clause within the public schools. Specifically, in the eight cases in which the Court assessed the merits of an Establishment Clause challenge to an arguably religious practice (school prayer, moment of silence, and so on) in a public school, it has struck that practice down as unconstitutional. (The eight cases are Edwards, Epperson, School District of Abington Township v. Schempp, Engel v. Vitale, Stone v. Graham, Wallace v. Jaffree, Lee v. Weisman, and Santa Fe Independent School District v. Doe.) The Court has given a variety of reasons for strictly applying the Establishment Clause in the public school context, including the compulsory nature of public education, the authoritative role that teachers play in the classroom, and the impressionable nature of young children and adolescents. As a result, any attempt to introduce intelligent design into the public school science classroom will have to pass a high hurdle to survive constitutional challenge. 


\section{Intelligent Design: Is it Religion?}

Logically, the first issue to consider is whether intelligent design is religion, as that term is used in the First Amendment. If it is, then schools may not advance, endorse, or promote it in the classroom. Perhaps surprisingly, the Supreme Court has never defined the term religion in the First Amendment, although it has hinted in some non-binding language that the term should be understood quite broadly to encompass, for example, more than traditional Judeo-Christian monotheism (Torcaso $v$. Watkins, 495n11). Lower courts struggling to give the term some meaning have adopted a test that asks whether the belief system in question is a comprehensive viewpoint that addresses fundamental questions and is associated with certain formal and external signs common to most religions, such as holidays, symbols, and professional clergy. (For example, this test was adopted by the Third Circuit Court of Appeals in Africa v. Pennsylvania.) Defenders of intelligent design's constitutionality (such as Beckwith 2003: 152) have argued that under this framework intelligent design is not a religion; they argue that intelligent design lacks the external attributes of most religions, is an isolated teaching rather than a comprehensive one, and does not address "fundamental and ultimate questions having to do with deep and imponderable matters." Although these writers may underestimate the extent to which intelligent design addresses fundamental questions, they are probably on strong ground to conclude that under this particular test, intelligent design does not constitute a religion.

This test, however, cannot be the right test for evaluating the constitutionality of intelligent design. If it were, then schools could also encourage students to pray, since the concept of prayer, by itself, does not meet the three-part test either. Likewise, if the analysis of the intelligent design supporters were correct, then schools could teach the truth of karma, sin, reincarnation, or any other indisputably religious concepts because none of these concepts by itself would meet the three-part test. These obvious examples demonstrate that courts must apply a different test when the issue is whether some concept, practice, or belief in isolation is religious, as opposed to whether some integrated belief system counts as a religion.

The courts have not explicitly recognized this problem, but the right analysis for the question would ask whether the concept, practice, or belief in question resonates in religion rather than in some other area of inquiry, such that a reasonable person would understand the government promotion of the concept as a promotion or endorsement of a religious practice or belief. Reasonable inquiries under such a test would include whether an average person would associate the concept primarily with religion; whether the concept is an important aspect of the religious traditions that people are generally familiar with; whether people also commonly associate the concept with ideas or belief systems that are not generally viewed as religious; and whether, if the concept is associated with non-religious belief systems, it is more prominently associated with those belief systems than with religious traditions.

Although application of this test might be difficult for some potentially religious concepts, intelligent design is in fact quite easy to analyze under the framework. Does intelligent design resonate in religion? Does the notion that an intelligent designer created the world and all of its inhabitants resonate in religion? Of course it does. The intelligent design of the universe is the core concept of the major prominent Western religions, without which those religious traditions would not be recognizable. Most reasonable people would associate the intelligent design of the universe with religion. No significant nonreligious school of thought has an intelligent designer or creator as a core concept. And the Supreme Court in Edwards specifically characterized as a "religious viewpoint" the belief that "a supernatural being created mankind." Thus, it seems clear that intelligent design should be considered a "religion" for First Amendment purposes.

Whether intelligent design constitutes "religion" may, however, be largely beside the point. After all, although public schools cannot promote or advance or endorse or teach the truth of any religion, they are perfectly free to teach about religion. They can teach about Christianity, about Judaism, about Hinduism, and about Confucianism, and there are many good reasons for schools to teach these subjects. (For an extended argument that schools should teach about religion to prepare them for civic life in a nation [and world] populated by believers of many religious traditions, see Wexler 2002b.) So, if public schools can teach about religion, why shouldn't they be able to teach about intelligent design? To some degree they certainly can. For example, if a public school chose to teach about the philosophical claims of intelligent design in a philosophy of science class, the intelligent design movement in a current affairs class, or about the truth claims of intelligent design in a comparative religion class, most likely these choices would not pose a constitutional problem, assuming that intelligent design is not presented as a true accountscientific, religious, philosophical, or otherwise - of the world's creation.

Things are very different, however, when schools propose to teach intelligent design as a legitimate alternative scientific theory to evolution. For one thing, because science teachers are generally expected to present the best thinking in the field as the current state of knowledge, without pointing out each and every dissenting view, even well-intentioned teachers trying to paint a balanced picture 
may end up leaving students with the impression that intelligent design is in fact true. This problem is exacerbated by the lack of adequate materials for teachers to use to teach evolution and intelligent design together in an objective fashion. Most important, however, even a policy that urges schools to use an objective approach to teaching about intelligent design might constitute an unconstitutional endorsement of religion or be motivated by a predominantly religious purpose, such that the very adoption of the policy would be unconstitutional. Whether this would be the case turns in large part on the proper understanding of the Supreme Court's decision in Edwards, to which I now turn.

\section{Intelligent Design and the Edwards Case}

Recall that in striking down Louisiana's equal-time-forcreation-science law, the Supreme Court looked to a number of factors in determining that the legislature's articulated secular purpose was a sham. Among those factors were the poor fit between that purported purpose and the actual language of the statute, the singling out of evolution for special treatment, the long history of religious opposition to evolution, and statements from the law's sponsors indicating an intent to promote religion. As it turns out, the intelligent design movement shares many of the same problems that doomed the creation-science movement over twenty years ago. Stated strongly, the Establishment Clause case against intelligent design can be summarized in terms of the Edwards factors as follows: Against a long and visible history of clearly religious opposition to teaching evolution, once more a movement arrives that speaks in explicitly religious terms and singles out evolution from among all topics in the school curriculum for change, with the stated goal of informing students about a significant scientific controversy which in fact does not exist. What message would a school send to a reasonable observer by embracing such a movement? Most likely, the reasonable observer would understand that the government has reformed the curriculum for religious reasons, which is precisely what the Court in Edwards said the government may not do. The following discussion focuses on three of intelligent design's most damaging constitutional problems: its singling out of evolution education for reform, its explicitly religious background, and its status as unsuccessful science.

First, like the iterations before it, the intelligent design movement singles out evolution as the one subject in the entire curriculum that deserves criticism. This demonstrates that the real intention of the movement is not to promote any secular goal but rather to promote a religious viewpoint, and it also ensures that the message received by reasonable observers will be the same. To understand this better, consider what a policy that truly sought to promote real secular goals would look like. For example, if reformers sincerely intended to make sure that students understand minority views on science, or the process of science as a discipline that is in constant flux as new discoveries are made and explanations developed, then why would those reformers focus exclusively on evolution (or even exclusively on targets of political conservatives, like global warming along with evolution) rather than on subjects throughout the entire science curriculum? Indeed, several real-world proposals exist to teach students about the scientific process and minority views across various scientific disciplines. An example is the program developed at the University of Wisconsin-Stout called "The Stout Science Program for Educators," which, according to its mission statement, "is designed to provide teachers with the tools necessary to improve student competencies in science and critical thinking...by using good science and pseudoscience (or false science) as an instructional tool." (The program's website can be found at http://physics.uwstout. edu/stoutsci/.) But intelligent design supporters do not appear to be rushing to support these efforts.

Likewise, although intelligent design proponents often complain that the public school curriculum is not neutral with respect to religious views, a complaint that is at the same time both true and inevitable, they surely are not proposing to reform the curriculum so that it is completely neutral with regard to every religious belief held by anyone in the community. For example, some religious traditions teach that the world was created by numerous deities or by an animal such as a turtle or a raven, often in a very specific fashion that does not involve the simple creation of life by an intelligent agent. (For a description of a wide variety of creation stories, see Leeming and Leeming 1994.) Teaching intelligent design is no more neutral with regard to these specific creation beliefs than teaching evolution is, but one does not find intelligent design advocates suggesting that public schools should teach a wide variety of creation stories in order to maintain neutrality in the public school curriculum.

The troubling focus on singling out evolution for reform signals an important potential constitutional problem for the emerging "arguments against evolution" movement, which seems, in the aftermath of Kitzmiller, to be in the process of becoming a major battleground for future evolution wars (see, e.g., Matzke and Gross 2006 on the battle over the 2005 Kansas science standards). Although a full constitutional analysis of this movement falls beyond the scope of this article, it is worth pointing out that, as with the creation science and intelligent design movements, the notion that schools should teach minority critiques of only one specific scientific theory rather than all similarly situated theories is 
vastly underinclusive with regard to any possible secular goal that could be articulated to support it. As a result, anyone trying to understand why some public school system would make a conscious decision to teach widely rejected criticisms of only evolution (and not, say, gravity, or the roundness of the earth, or some other widely accepted scientific notion) would surely surmise that the reform was intended to promote the clearly religious view that evolution is an unconvincing scientific position.

Second, as with past efforts to discredit evolution, the intelligent design movement also often speaks in explicitly religious terms, thus compounding the religious message that any reasonable observer would take from the attempt to adopt an intelligent design policy in the public schools. There are two general ways that the movement can be understood as speaking in religious terms. First, the founders and leaders of the movement-people such as Phillip Johnson and William Dembski and organizations such as the Discovery Institute - often talk generally about intelligent design using religious language. Second, the political decision-makers who make the actual decision to implement some particular intelligent design policy in a specific public school or school system may also speak in explicitly religious terms during the lead-up to implementation, as well as its follow-through.

Much more can be said in concrete terms about the first of these than the second. As the federal judge in Kitzmiller rightly pointed out, many of the most prominent individual and institutional supporters and developers of intelligent design have consistently spoken about it in religious terms. Perhaps most damning on this score is the so-called Wedge document, which stated one goal of the intelligent design movement as "replac[ing] materialistic explanations with the theistic understanding that nature and human beings are created by God." And as made clear by Barbara Forrest at the trial, the various drafts of the primary intelligent design textbook Of Pandas and People demonstrate that the authors simply replaced the terms creation and creation science with intelligent design to avoid running afoul of the Supreme Court's decision in Edwards. (For the judge's account of this religious language, and the Wedge document in particular, see Kitzmiller, 718-723. A comprehensive account of this history can be found in Forrest and Gross 2003.)

Less can be said about the language used during the deliberations over any specific intelligent design policy because, of course, that language will differ depending on the circumstances. It is at least theoretically possible that a school could adopt an intelligent design policy without talking in religious terms at all. For example, an individual science teacher could introduce the topic into a classroom without mentioning religion, assuming there is no contrary school policy in place. If there is a scenario for introducing intelligent design in a science class that could possibly pass constitutional muster, it would involve such an individual teacher who sincerely thinks intelligent design is an interesting scientific concept for reasons truly unrelated to religion and says exactly that upon introducing the subject. On the other hand, it seems far more probable that most decisions to adopt intelligent design would resemble the situation in Dover, Pennsylvania, where supporters and school board members spoke in favor of the policy in explicitly religious terms, with one member saying something like, "Two thousand years ago someone died on a cross. Can't someone take a stand for him?" Language like this quite obviously will weigh in favor of finding any specific intelligent design policy unconstitutional.

It is important when analyzing religious language that is used in support of some government policy or legislation, however, that courts be careful not to place too high a bar on the use of religious language during the policy-making or legislative process. Like all individuals, government officials possess First Amendment rights, and a liberal democracy that treats religious citizens with respect and equal regard should not censor too strongly the invocation of religious beliefs that happen to coincide with some public policy decision (for more on this point, see Wexler 2002a). A law should not find itself in constitutional jeopardy simply because some citizens speak in its favor in religious terms; if that were the law, neither the abolitionist nor the civil rights movement would have fared well in the courts. Religious statements in support of a challenged government policy or law become problematic only when they so suffuse the decision-making process that they demonstrate that the law was promulgated predominantly for a religious purpose or they contribute to sending a message to the reasonable observer that the government is endorsing a religious belief. This is what happened, for example, in the Dover case.

Finally, and perhaps most importantly, as with the creation-science equal-time law at issue in Edwards, the intelligent design movement suffers from an enormous disconnect between the movement's means and its purported ends. To the extent that the movement argues that public schools should teach intelligent design in science classes to inform students of an important scientific controversy, it fails because there is no such controversy. As its critics have explained in detail, intelligent design has found no success in the scientific community. That community, including almost every major scientific organization, has universally accepted evolution as a central theory in biology and roundly rejected the concept of intelligent design as an alternative to evolution. Most important, perhaps, is intelligent design's near total failure to make any headway into the peer-reviewed publications that are the gateway to scientific success. With this justification for teaching intelligent design completely undermined by the 
facts, what possible reason could there be to teach it in science classes, other than to discredit a theory that many religious people find untrue and offensive? As a result, the message sent by any school that adopts an intelligent design policy will almost surely be that it intends to promote the religious belief that an intelligent designer created the universe.

\section{The Kitzmiller Decision}

As of this writing, the issue of intelligent design's constitutionality has been addressed by the courts only one time. In late December 2005, Judge John E. Jones III, a United States district court judge sitting in Harrisburg, Pennsylvania, issued a 139-page ruling striking down as unconstitutional an intelligent design policy adopted by the Dover Area School Board in Dover, Pennsylvania the previous year. The challenged policy included two parts. First, the Board had adopted a resolution stating: "Students will be made aware of gaps/problems in Darwin's theory and of other theories of evolution including, but not limited to, intelligent design." Second, the Board had issued a statement, required to be read to ninth grade biology students in the district, which said in full:

The Pennsylvania Academic Standards require students to learn about Darwin's Theory of Evolution and eventually to take a standardized test of which evolution is a part.

Because Darwin's Theory is a theory, it continues to be tested as new evidence is discovered. The Theory is not a fact. Gaps in the Theory exist for which there is no evidence. A theory is defined as a well-tested explanation that unifies a broad range of observations.

Intelligent Design is an explanation of the origin of life that differs from Darwin's view. The reference book, Of Pandas and People, is available for students who might be interested in gaining an understanding of what Intelligent Design actually involves.

With respect to any theory, students are encouraged to keep an open mind. The school leaves the discussion of the Origins of Life to individual students and their families. As a Standards-driven district, class instruction focuses upon preparing students to achieve proficiency on Standards-based assessments.

After various parents of children in the Dover school system sued to enjoin the policy, Judge Jones conducted a trial over the course of six weeks to consider whether the policy violated the Establishment Clause. His comprehensive opinion in the case of Kitzmiller v. Dover Area School
District, finding the school board's intelligent design policy unconstitutional, was widely hailed as a tremendous victory for defenders of evolution.

Judge Jones's legal analysis proceeded in six logical steps. First, the judge concluded, based on his analysis of precedent from both the Third Circuit Court of Appeals (the appellate court that reviews his decisions) and the Supreme Court, that he would apply both the Lemon test and the endorsement test to the school board's actions. Second, he analyzed the historical development of the intelligent design movement, including its roots in medieval theology and creation science, as well as the religious language invoked by its supporters, and concluded that an objective observer would understand intelligent design to be a religious strategy "that evolved from earlier forms of creationism." Third, he considered how a reasonable student in the Dover schools would view the policy. Looking at the impressionable nature of the students, the specific language of the disclaimer, and the circumstances surrounding the classroom presentation of the disclaimer, the judge found that "an objective student would view the disclaimer as a strong official endorsement of religion or a religious viewpoint." Fourth, he concluded that reasonable adults in the Dover community would reach the same conclusion, because the board defended the policy in a very public fashion through community meetings and a widely circulated newsletter that described the policy in expressly religious terms.

Although Judge Jones could have ended his analysis at this point, he nonetheless proceeded to consider two other issues that he deemed important to evaluating the constitutionality of the board's policy. Thus, the opinion's fifth conclusion was that intelligent design is not science. The judge rested this determination on his judgment that intelligent design fails to follow the ground rules of science by relying on supernatural explanations, that it uses "the same flawed and illogical contrived dualism that doomed creation science in the 1980s," and that it has been completely rejected by the scientific community. Finally, finding that "the better practice in this Circuit is for this Court to also evaluate the challenged conduct separately under the Lemon test," Judge Jones ended his opinion by finding that the Dover policy independently failed to pass constitutional muster because the school board that enacted the policy was animated by the primary purpose of advancing religion. On this score, the judge canvassed with painstaking detail the events leading up to the adoption of the school board's policy-including various public meetings and the donation of sixty copies of the intelligent design textbook Of Pandas and People to the school district - and concluded that the board's purported secular purposes were in fact a "sham."

It is somewhat difficult at this time to assess the future impact of the Kitzmiller decision on the intelligent 
design movement as a whole. On the one hand, the decision has precedential value in only one small district in central Pennsylvania and therefore does not prohibit another school district in some other area of the country from experimenting with intelligent design in its public schools. Thus, if a school district in Kansas or Ohio or Utah wants to introduce intelligent design into its science classrooms, Kitzmiller erects no legal barrier. On the other hand, the court's careful and detailed fact-finding, along with its persuasive and impressively complete legal analysis, will likely make school districts around the nation think twice (at least) about whether bringing intelligent design into their biology classes would really be worth the risks.

Judge Jones's opinion is too comprehensive to provide any type of exhaustive analysis here, but it is worth pausing to emphasize a few of the more important aspects of the decision. For one thing, Judge Jones appropriately spent most of his effort in the opinion applying the endorsement test to the school board's policy, a move that is not obviously dictated by the Supreme Court's case law. Although the Court has invoked the endorsement test in all sorts of cases involving challenges to many types of government action, including school funding and school prayer, the test is most relevant and useful to evaluating the constitutionality of religious displays, such as crèches, crosses, and the like, which send the message that government is favoring religion. Thus, the board argued in the case that the endorsement test was inapplicable to a curricular policy like the one at issue, especially given that the Court did not apply the test in either Epperson or Edwards, the two evolution cases previously to reach the Court.

Judge Jones's response to this argument was typically comprehensive and compelling. Not only did the judge make the obvious point that Edwards and Epperson predated the Court's adoption of the endorsement test, but he also noted that Edwards in fact did mention the endorsement idea; that the Court, having ruled against the government on purpose grounds in that case, would probably not have applied the endorsement test even if the test had existed at the time; and that both the Supreme Court and the Third Circuit Court of Appeals have consistently applied the endorsement test in cases not involving religious displays. But perhaps most importantly, the judge understood that the endorsement test is the test best suited to evaluating a policy such as the one adopted by the Dover School Board, because such a policy is problematic, more than anything else because it sends the harmful message that the government wants to change the curriculum to place a stamp of approval on a particular religious belief. The question of whether the school board had endorsed a religious message by adopting its intelligent design policy was therefore the central issue in the case, and Judge Jones rightly recognized it as such.

Of course, Judge Jones did not stop writing after finishing his endorsement analysis, and his decision to consider the purpose inquiry under the Lemon test as well was insightful and shrewd. Not only does the application of both tests make the decision more difficult to overturn in the unlikely case of an appeal (since the reviewing court would have to find the judge's analysis incorrect on both counts), but it also insulates the decision in the not entirely unlikely case that the newly constituted Supreme Court does away with the endorsement test. With the test holding on by only one vote, it is certainly possible that the test, which has been the object of substantial judicial and scholarly criticism (for example, McConnell 1990; Smith 1989), will be discarded by today's more conservative Court. If Judge Jones had not decided the case on both endorsement and purpose grounds, a decision by the Supreme Court to get rid of the endorsement test would leave the Kitzmiller decision on shaky ground indeed. This way, the Court would have to get rid of both the endorsement and the Lemon test for the judge's decision to lose force. Although this too is not impossible, as the Lemon test has also been widely criticized, it is far more unlikely that the Court would reject both prevailing tests than just one.

Finally, it should be of no surprise to anyone familiar with reading legal opinions that one of the judge's more astute and important conclusions can be found in a footnote. At trial, the school board had argued "vigorously" that the act of reading the evolution disclaimer in front of the classroom did not constitute the teaching of intelligent design but rather simply made the "students aware of it." As such, the board argued, the policy could not have violated the Establishment Clause. The judge rightly rejected this argument with a two-part response. First, he argued that the Establishment Clause not only prohibits the teaching of religion, but also forbids the government from endorsing or advancing religion generally, which can be accomplished by actions in the classroom short of teaching. But more fundamentally, the judge also accepted the argument, advanced by various teachers at the trial, that reading the disclaimer is in fact itself teaching. As the judge found: "[A]n educator reading the disclaimer is engaged in teaching, even if it is colossally bad teaching... The disclaimer is a 'mini-lecture' providing substantive misconceptions about the nature of science, evolution, and ID which 'facilitates learning"' (Kitzmiller 727n7). This notion that, given the teacher's authoritative position in the classroom, nearly everything he or she does there is in some real and important sense "teaching" is perhaps a subtle point, but it is surely true and potentially an important legal conclusion. Like so much in the opinion, 
this footnote demonstrates that Judge Jones had an impressively firm grasp not only on the formal legal issues raised by the school board's flawed policy, but on the realworld stakes it involved as well.

\section{Academic Freedom}

Advocates of intelligent design's constitutionality often argue that public school teachers have a First Amendment academic freedom right to teach intelligent design even if the school or school board has prohibited teachers from discussing the topic. For example, Francis Beckwith has argued that "bringing into the classroom relevant material that is supplementary to the curriculum (and not a violation of any other legal duties), when the public school teacher has adequately fulfilled all of her curricular obligations, is protected speech under the rubric of academic freedom" (Beckwith 2003: 76). According to another intelligent design supporter, "Public school teachers are protected in their classroom discussions by free speech and academic inquiry rights under the First Amendment speech rights" (Miller 2001: 500). In support of this argument, intelligent design advocates often cite language from Keyhishian $v$. Board of Regents, where the Supreme Court opined that the First Amendment "does not tolerate laws that cast a pall of orthodoxy over the classroom." In light of the rather devastating opinion in Kitzmiller, intelligent design advocates have turned away from promoting district-wide policies mandating the teaching of intelligent design and moved instead toward encouraging individual teachers to bring up the subject on their own, often through legislation purporting to grant "academic freedom" to teachers to present criticisms of evolution (Branch and Scott 2009). But what if the school has a policy (or subsequently adopts a policy) prohibiting such instruction? Would the teacher have the right to teach intelligent design anyway?

Intelligent design advocates are certainly correct to claim that the First Amendment places some limits on the state's authority to fire government employees, including public school teachers, and that those teachers do not completely give up their constitutional right to free speech when they accept a government job. The Supreme Court, in Pickering v. Board of Education, held that public school teachers have a limited right (subject to a balancing test, in which the court weighs the interest of the speaker against the countervailing government interests) to speak as citizens on matters of public concern without having to fear that their employers will fire them or otherwise take negative employment action against them. But this right to speak out as citizens, in forums such as newspaper editorials or public meetings, is completely different from the asserted right to include material or views in the classroom in violation of orders from the government-controlled supervisory body. This latter right simply does not exist. As the Supreme Court recently explained, "When public employees make statements pursuant to their official duties, the employees are not speaking as citizens for First Amendment purposes." (Garcetti v. Ceballos 421).

The Court has never held that public secondary school teachers have any independent "academic freedom" right. The words academic freedom do not appear anywhere in the Constitution, and although the phrase can occasionally be found in non-binding language from the Supreme Court, that Court has never relied upon an academic freedom rationale to invalidate any government law or practice. As the Fourth Circuit Court of Appeals recently explained, "[T]he Supreme Court has never set aside a state regulation on the basis that it infringed a First Amendment right to academic freedom.... [T]o the extent it has constitutionalized a right of academic freedom at all, [the Court] appears to have recognized only an institutional right of self-governance in academic affairs" (Urofsky v. Gilmore 412).

Moreover, courts that have recently considered the issue have generally rejected the notion that government employees have any First Amendment right to speak in their role as employees in violation of the dictates of their democratically accountable supervisors. This means that even if a teacher may have a right to speak out as a private citizen in favor of intelligent design (or unprotected sex or communism or any other unpopular idea) in a public meeting or newspaper editorial without fear of being fired, the same teacher does not have the same right to advocate those ideas inside the classroom, if the school (or school board or state) has provided clear notice that the teacher may not teach those subjects, or otherwise provided the teacher with adequate due process protections. Again, the Fourth Circuit made this clear when it explained that before applying the Pickering balancing test to a public employee, the court must decide whether the employee is speaking as a citizen or as an employee: "This focus on the capacity of the speaker recognizes the basic truth that speech by public employees undertaken in the course of their job duties will frequently involve matters of vital concern to the public, without giving those employees a First Amendment right to dictate to the state how they will do their jobs" (Urofsky v. Gilmore 407). The Supreme Court recently agreed with this analysis. (Garcetti v. Ceballos).

This is entirely sensible. If high-level government officials cannot restrict the official speech of their employees, then those employees (including teachers) would have nearcomplete authority to countermand the state's official messages. The Fourth Circuit invokes the example of a formal press conference where an assistant district attorney criticizes his boss's decision to pursue a murder charge, but one can 
imagine an endless stream of analogous examples where adopting this academic freedom argument would disrupt the government's functioning. Should the president's press secretary be free to criticize the administration's social policy? Should a scientist from the Environmental Protection Agency be able to officially state that some type of pollution is far less dangerous than the Administrator has recognized? Should a state employment officer be able to officially speak out against the state's pro-labor policies? These examples demonstrate the chaotic results of recognizing a First Amendment right for a subordinate to speak in his or her official capacity on matters of public concern.

Recognizing a strong First Amendment speech right for state employees acting as employees would be just as problematic in the public schools as it would be anywhere else in the government. Intelligent design supporters do not propose any principled way to limit their academic freedom argument to the intelligent design context, which is unsurprising, since no principled limit exists. As a result, teachers could teach their personal views on a whole smorgasbord of controversial topics, and the school would be unable to stop them. Teachers could supplement a sex education class with their own views about how HIV is really transferred, suggest that the federally funded abstinence lesson they just taught is a "bunch of crapola," mention at the end of their health lesson that drugs are in fact "kind of a blast," hint that the horrors of the Holocaust have been a "bit overstated," or argue that slavery was a mutually beneficial economic arrangement for blacks and whites alike.

Allowing government supervisors to control the official statements of their subordinates ensures that government decision-makers remain democratically accountable for the official messages of the state. Those who speak on the state's behalf are ultimately speaking for its citizens, and those citizens ought to be able to take some action if the state decides to take an official position that the citizens disagree with or find offensive. The electoral process gives citizens this power, but only for the highest level officials. From a democratic standpoint, then, it makes sense that those highest level officials ought to have the final say with respect to what messages the state will espouse (so long, of course, that these messages do not otherwise violate the Establishment Clause or any other part of the Constitution). If the courts adopted the position urged by supporters of intelligent design, then citizens would lose any real power to hold the government accountable for its statements in cases where an employee makes an official statement on a controversial subject that contradicts the state's own message. So, if a public school teacher decides to teach that the Holocaust never happened, the community should have the power to pressure the school board to prohibit the teacher from advancing this view in the classroom. If the board can control the teacher's speech, and the board agrees with the community, then the board can fire the teacher if the teacher persists in teaching the objectionable viewpoint. If the board, on the other hand, decides not to reprimand the teacher, the community can remove the relevant members from the board at the next election. But if the teacher possesses a First Amendment right to say what he or she wants, there will be nothing that the community can do to stop the teacher from continuing to engage in the unwanted speech.

Some scholars, such as Beckwith, argue only that a teacher has the right to supplement the existing evolution curriculum with intelligent design theory, rather than that a teacher has a First Amendment right to replace the prescribed curriculum by teaching intelligent design theory instead of evolution (Beckwith 2003: 76). This distinction makes no difference, however. There is no reason to think that the analysis should be any different just because the employee first says what she is supposed to say before putting forth her own opinion. A First Amendment rule allowing supplementation of the curriculum but not replacement of curricular content would still undermine the functioning of government and obstruct the lines of democratic accountability. Should the president's press secretary really be able to officially state that "the president believes his social policy is just, but he is sadly mistaken"? Should the First Amendment really protect a public school teacher who wants to tell his class that, "Most people believe that the Holocaust happened, but I have to say that the evidence looks a little thin to me," or "the principal thinks you shouldn't have sex, but I think he's sort of overreacting," if the community strongly disagrees with these statements?

Finally, it is worth emphasizing that nothing said here is intended to suggest that schools should generally restrict what their teachers may say in the classroom. Strong educational policy arguments surely exist for allowing teachers wide latitude to teach the material they wish in whatever way they want, even if sometimes their methods or materials may be controversial. Providing teachers this freedom also sends the essential message that teachers are respected professionals whose work is vital to the effective functioning of a democracy and the well-being of its citizens. Indeed, probably in almost all cases, school boards should allow teachers great leeway to do what they want when they are in front of their classes. This conclusion, however, is based on sound educational policy, not constitutional law. Taking the position that schools should usually allow teachers to supplement the curriculum with their own views is far different from saying that teachers have a First Amendment right to supplement the curriculum with their own controversial viewpoints in those isolated cases where the community strongly opposes that viewpoint. The latter purported "right" is unsupported by constitutional text or precedent and contrary to common sense and the ideals of the political community. 


\section{Conclusion}

The current dispute over teaching intelligent design in public school classrooms is the most recent chapter of the longstanding controversy over how schools ought to present the theory of evolution in their science classes. From time to time, democratically elected majorities have succeeded in implementing policies intended to undermine the teaching of solid science. Each time this has happened, however, these classroom initiatives have failed in the nation's courtrooms. The judges sitting in these courtrooms have uniformly realized that given evolution's commanding support in the scientific community, attempts to weaken evolution's status in the classroom are constitutionally suspect. As long as evolution continues to hold the dominant position in the scientific community that it has occupied for most of the past century, courts will likely continue to look at attempts to discredit it with similar disfavor.

Acknowledgments This article is a slightly revised and updated version of Jay D. Wexler, "From the Classroom to the Courtroom: Intelligent Design and the Constitution," pp. 83-104 of Not in Our Classrooms: Why Intelligent Design is Wrong for Our Schools, edited by Eugenie C. Scott and Glenn Branch (Boston: Beacon Press 2006). Much of the discussion is adopted or taken directly from several other articles I have written about intelligent design. Jay D. Wexler, "Of Pandas, People, and the First Amendment: The Constitutionality of Teaching Intelligent Design in the Public Schools," Stanford Law Review 49 (1997): 439-470; Jay D. Wexler, "Darwin, Design, and Disestablishment: Teaching the Evolution Controversy in Public Schools," Vanderbilt Law Review 56 (2003): 751-855; Jay D. Wexler, "Intelligent Design and the First Amendment: A Response," Washington University Law Quarterly 53 (2006): 63-98.

\section{References}

Beckwith FJ. Law, Darwinism, and public education: the establishment clause and the challenge of intelligent design. Lanham MD: Rowman \& Littlefield; 2003.
Branch G, Scott EC. The latest face of creationism. Sci Am. 2009;300 (1):92-9.

Forrest B, Gross PR. Creationism's Trojan Horse: the wedge of intelligent design. New York: Oxford University Press; 2003.

Leeming D, Leeming M. A dictionary of creation myths. New York: Oxford University Press; 1994.

McConnell MW. Religion at a crossroads. Univ Chic Law Rev. 1990;59:115-94.

Smith SD. Separation and the "secular": reconstructing the disestablishment decision. Tex Law Rev. 1989;67:955-1031.

Matzke N, Gross PR. Analyzing critical analysis: the fallback antievolutionist strategy. In: Scott EC, Branch G, editors. Not in our classrooms: why intelligent design is wrong for our schools. Boston: Beacon; 2006. p. 28-56.

Miller NP. Life, the universe and everything constitutional: origins in the public schools. J Church State. 2001;43:483-510.

Wexler JD. Framing the public square. Georget Law J. 2002a;91:183218.

Wexler JD. Preparing for the clothed public square: teaching about religion, civic education, and the Constitution. William Mary Law Rev. 2002b;43(3):1159-263.

\section{Legal cases cited}

Africa v. Pennsylvania, 662 F.2d 1025 (3d Cir. 1981)

County of Allegheny v. ACLU, 492 U.S. 573 (1989)

Capitol Square Review \& Advisory Board v. Pinette, 515 U.S. 753 (1995)

Edwards v. Aguillard, 482 U.S. 578 (1987)

Engel v. Vitale, 370 U.S. 421 (1962)

Epperson v. Arkansas, 393 U.S. 97 (1968)

Garcetti v. Ceballos, 547 U.S. 410 (2006)

Keyhishian v. Board of Regents, 385 U.S. 589 (1967)

Kitzmiller v. Dover, 400 F. Supp. 2d 707 (2005)

Lee v. Weisman, 505 U.S. 577 (1992)

Lemon v. Kurtzman, 403 U.S. 602 (1971)

Pickering v. Board of Education, 391 U.S. 563 (1968)

Santa Fe Independent School District v. Doe, 530 U.S. 290 (2000)

School District of Abington Township v. Schempp, 374 U.S. 203 (1963)

Stone v. Graham, 449 U.S. 39 (1980)

Torcaso v. Watkins, 367 U.S. 488 (1961)

Urofsky v. Gilmore, 216 F.3d 401 (4th Cir. 2000)

Wallace v. Jaffree, 472 U.S. 38 (1985) 